IRSTI 06.71.07

UDC 330.341:316.4

ZH.E. ABILGAZIYEVA, ${ }^{1}$

c.e.s.

G.R. DUISEMBEKOVA, ${ }^{2}$

c.e.s.

A.N. RAMASHOVA, ${ }^{2}$

$\mathrm{PhD}$.

M. Saparbayev South Kazakhstan

Humanitarian Institute. ${ }^{1}$

M.O. Auezov South Kazakhstan

State University ${ }^{2}$

\title{
ECONOMIC EFFICIENCY OF BIOLOGICAL METHODS USE OF PLANTS PROTECTION
}

\begin{abstract}
The economic efficiency of the application of biological methods of plant protection is investigated. The analysis of the state of agriculture and, in particular, crop production in the Turkestan region. The foreign experience of using biological methods of plant protection is studied and the ways of their application in Kazakhstan are determined. The classification of rural areas is made according to indicators characterizing social and economic development, including economic potential. The essence of plant protection methods is determined; calculations of the economic efficiency of the use of bioagents on the sown areas of cotton in the Maktaaral district of Turkestan region; the foreign experience of applying biological methods of plant protection was studied and the ways of its implementation in Kazakhstan were examined; calculation of the need for biological laboratories, the results of the study are generalized. The authors substantiated the effeciency of the application of biological methods of plant protection. In many agricultural formations of the Turkestan region, drip irrigation systems are used. As it is known, in this case, with higher air humidity in the region of the trunk and near the leaf surface, the effeciency of the use of biological products becomes higher, since in conditions of high humidity, bacteria and fungi, which are the basis of the active substance, are more productive and virulent.
\end{abstract}

Key words: classification, biological methods, plant protection, economic potential, biological product, biolaboratory, high humidity, resources, irrigation system, area, efficiency assessment.

As world experience shows, improving the efficiency of agriculture is impossible without an organized system of plant protection. Today, the protection of plants from pests is the primary factor determining high yields. Like all living organisms, including humans and animals, plants need not only good nutrition, favorable development conditions, but also protection from diseases and pests. This study has a high prospect rating in terms of the application of biological methods of plant protection that have such positive properties: high efficiency against target pests, human safety, lack of toxicity, as well as negative impact on the quality of crop production, lack of danger of accumulation in the environment and commercial production of toxic substances, lack of addiction factor, the possibility of application at any stage of the vegetation of plants. Biological methods are based on the use of natural biological approaches (entomopathogenic microorganisms, beneficial insect entomophages, various plant extracts) and the regulation of the number of pests (insect pests, diseases, weeds).

Alarge number of species of organisms useful for biomethods are known in the world, but in practice a little more than 70 are used, including microorganisms and entomophages. The use of chemical plant protection products leads to the most adverse consequences - pollution of the environment, as well as agricultural products, residues of chemicals, including heavy metals, nitrates, other elements harmful to human health, as well as the emergence of pest-resistant species of pests and the destructive effect of pesticides on ecological system.

The greatest interest in biological methods of plant protection is associated with trends in the general ecologization of the environment, the efficient use of natural resources, and concern for the health of the nation. However, the biologization of agriculture involves the use of biological agents in order to increase soil fertility and increase crop yields. Scientists have proven that the economic efficiency of using biological plant protection methods is $70-80 \%$ effective compared to chemical means of protection. 
Methods of research: biological methods of plant protection, evaluating their economic efficiency, abstract-logical, monographic, economic-statistical.

An important role in improving the efficiency of agricultural production is played by the plant protection system. In Kazakhstan's crop production, the pest control is dominated by the chemical control method, which leads to the pollution of water bodies, soils, the accumulation of harmful substances in crop production, which subsequently have a negative effect on human health (cause various oncological and allergic diseases, infertility, pathologies in newborns etc.) At the same time, the resistance to pesticides of plant pests increases and the effectiveness of their use decreases. Radical measures are being taken around the world to reduce the use of pesticides, and in some cases, for example, in the production of freshly consumed agricultural products and in the production of food for children they are not used at all. On January 13, 2009, the European Parliament decided to abandon the use of pesticides and introduce additional provisions to ban them. To this end, they provide subsidies to agricultural producers receiving environmentally friendly products; a sustainable agriculture concept has been developed that provides for the principles of production of high-quality products.

In the agricultural production of Germany, France, Sweden, Austria and other European countries, emphasis is placed on biological methods of plant protection and increasing soil fertility, i.e., a biological farming system is being implemented.

For the first time, successful experiments with the use of beneficial insects were conducted in China, where there were uses of predatory ants against caterpillars. In 1855, the American entomologist Fitch A. attempted to acclimatize one of the wheat mosquito parasites in the United States. The most active and effective research was begun at the end of the 19th century. In the United States, pests brought from other countries acclimatize entomophages: from Australia to California for the destruction of the Australian grooved worm-carnivorous beetle rhodolio (1888), the mealybug - cryptolemus (1892). At the beginning of the 20th century, a complex of uncommon silkworm entomophages was introduced from Europe and Japan. In the seventies of the twentieth century in the United States, out of 520 species of introduced entomophages, only 115 species were acclimatized.

In Russia, the first studies on biological methods of plant protection were carried out by Mechnikov I.I. (1879), who used the green muscardine fungus against the bread beetle and beet weevil. The works of Krasilshyk I.M., Porchinski I.A., Vasilyev P.V., Kurdumov U.V., Shevirev I.Y., Pospelov N.A., Telenga N.Aand other scientists are of great importance.

Among Kazakhstani scientists-researchers of the biological method of plant protection, the works of Sagitov A.O., Marikovsky P., Ashikbaeva N.Zh., Duysembekova B.A., Ismukhambetova Zh.D., Aitbaeva Zh.A, Matpaeva B.B are of particular interest.

Despite the successes achieved in crop protection, according to the FAO (Food and Agriculture Organization of the United Nations), about $30 \%$ of the crop die annually due to pests and diseases. Only in vegetable crops, there are hundreds of pests. Of these, scoops, aphids, and whiteflies are especially dangerous. For example, in the South Kazakhstan region, 40-50\% of the crop dies due to cotton aphids, and whiteflies and spider mites eat up 15-20\%.

The scale of application of the biological method of plant protection in greenhouses is increasing from year to year. For example, in some federal states of Germany, the share of the biological method of plant pest control reaches $97 \%$ of the complex of measures for plant protection [1].

The development of a biological plant protection system, the introduction of a biomethod in agricultural practice is the most pressing issue. Thanks to the efforts of domestic scientists of the Kazakh Research Institute of Plant Protection and Quarantine, a modern bio-laboratory was created in 2010 in the Maktaaral district of the Turkestan region. On the territory of the district as of June 1, 2019. There are 10 biological laboratories and 9 biological factories for the production of beneficial insect bioagents: "Bahyram Kazhy", "Kulanda", "Zhanar", "Inter-T" LLP, "Ketebay", "Altyn Kaz", "South Kazakhstan Experimental Biofactory”, “Toykul”,"Alatau”,"Zhetisay”,"Atakent”,"AkAltyn" "Nesibeli" "BIO LIFE" LLP, etc.

Pest control is carried out by multiple resettlement of beneficial insects that breed in biological laboratories. All cotton fields are processed on average 9-10 times [2].

According to biofactories and biological laboratories, the average cost of production of biological plant protection products is: 1 gram of trichogram 310 tenge, 1 gabrobracon 2.48 tenge, 1 lacewing 1.75 tenge. If we take into account that the percentage reduction in the cost of one unit of subsidized 
bioagents and biological products purchased from suppliers of bioagents is currently $40 \%$, then the cost of biological protection of cotton, respectively, is reduced by $40 \%$. As simple economic calculations show, the cost of bioagents per 1 hectare of cotton will total 8643 tenge. The amount of the subsidy is 3457 tenge, the actual costs of raw cotton producers for pest control will amount to 5186 tenge. As experience has shown, the application of the biological method of plant protection is much more effective and cheaper than chemical protection, and it can be used not only when growing cotton, but also vegetables and fruits. For the economic justification of the organization of protective measures in the country, determining the rational level of application of pesticides, the need for chemical, biological and microbiological agents, the equipment for their application, storage facilities for storage, and vehicles for transportation, it is important to solve the following issues:

1) assessment of the potential danger of crop losses from pests, pathogens and weeds at a specific level of agriculture;

2) assessment of the economic efficiency of the use of plant protection products to prevent crop losses;

3 ) the search for ways to increase the economic efficiency of plant protection products [3, 4].

The need for biological laboratories and biological factories is determined, first of all, by the area and structure of crops of agricultural crops. The data on sown areas are given for the types of farms that are represented by agricultural enterprises, peasant or farm enterprises and households (subsidiary farms). Most of the areas - 258.9 thousand ha or 31.6\% - are occupied by cereals (including rice) and legumes, 252.4 thousand ha or $30.9 \%$ - technical, 197.2 thousand ha or $24.1 \%$ - fodder and 109.6 thousand ha or $13.4 \%$ - potatoes, vegetable and melon crops. Compared to the previous year, the sown areas of wheat increased by $6.8 \%$, cotton - by $22.8 \%$, safflower - by $51.0 \%$. At the same time, barley sown areas decreased by $25.6 \%$, corn for grain - by $6.6 \%$, rice - by $31.3 \%$, sunflower $-17.2 \%$, potato $-6.5 \%$, vegetables $-6.6 \%$, melons - by $2.4 \%$, fodder crops - by $11.4 \%$. The largest share of sown areas for crops falls on the following areas: Saryagash -42.4 thousand ha (16.4\%), Kazygurt 39.6 thousand ha (15.3\%), Baidibek - 37.4 thousand ha (14.5\%); oilseeds - Baidibek - 41.5 thousand ha $(35.3 \%)$, Tulkubas -18.3 thousand ha $(15.6 \%)$, Kazygurt - 17.5 thousand ha $(14.9 \%)$; potatoes Saryagash -5.6 thousand ha $(39.0 \%)$, Sairam - 3.5 thousand ha $(24.6 \%)$; Tolebi -1.3 thousand ha $(8.8 \%)$; vegetables - Saryagash -14.4 thousand hectares $(38.1 \%)$, Sairam -4.4 thousand hectares $(11.7 \%)$, Maktaaral -3.9 thousand hectares (10.3\%); melons - Maktaaral - 25.3 thousand ha (43.9\%), Shardara -8.8 thousand ha (15.3\%); fodder crops - Tolebi - 28.7 thousand ha (14.6\%), Kazygurt - 24.5 thousand ha $(12.4 \%)$, Shardara -22.4 thousand ha (11.3\%), Tulkubas -21.9 thousand ha $(11.1 \%)[5$, $6,7]$.

Calculation of the need for biological laboratories based on the performance of a typical biofactory and biological laboratory is developed in the following table 1.

Table 1 - Calculation of the need for biological laboratories based on the performance of a typical biofactory and biolaboratory

\begin{tabular}{|l|c|c|}
\hline $\begin{array}{c}\text { Rural areas } \\
\text { of Turkestan region }\end{array}$ & Sown area, ha & $\begin{array}{c}\text { Calculation of the need for bio-laboratories } \\
\text { (with a typical bio-laboratory productivity of 2600 ha) }\end{array}$ \\
\hline Baidibek district & 88955,4 & 34 \\
\hline Kazygurt & 82776,5 & 32 \\
\hline Maktaaral & 138210,8 & 53 \\
\hline Ordabasy & 55172,1 & 21 \\
\hline Otrar & 28050,0 & 11 \\
\hline Sairam & 47188,5 & 18 \\
\hline Saryagash & 81724,2 & 31 \\
\hline Suzak & 13005,4 & 5 \\
\hline Tolebi & 64651,1 & 25 \\
\hline
\end{tabular}

Various natural-climatic, socio-economic, environmental factors, and their impact on the structure of crop production require certain adjustments in calculating the need for biological laboratories for rural areas of the Turkestan region. Consequently, timely biologization of protective measures against cotton pests in the south of Kazakhstan will stabilize the ecological situation in this region. 
In the Turkestan region, an analysis of the structure of sown areas showed the following. Over the past five years, the structure of cultivated areas has undergone significant changes due to changes in the climatic conditions in the region and the implementation of rural development programs [8].

Biolaboratory specialists carry out comprehensive research in the field of plant protection against pests, organize measures to combat pests and plant diseases, provide local agricultural producers with bioagents and provide plant protection services on a contractual basis. Plant protection measures are carried out with seeds that are etched with insecticides. In the cotton fields of the Maktaaral district of the Turkestan region, gold-eyes, a trichogram and a poop are used as bioagents.

The gabrobracon-rider paralyzes the caterpillar, lays eggs, from which the larvae that eat the moth are hatched. And if there is no moth, the gabrobracon destroys the scoop and moth. It is not difficult to breed it in laboratory conditions, and from there it can be delivered to the fields at the right time. As food for gabrobrackon larvae in artificial conditions, you can use the caterpillars of the mill fire, those same white worms that start in flour. Sown areas of grain crops in 2019 compared to 2010 decreased by 21 thousand hectares. Thus, the need for biological laboratories in the Turkestan region also depends on the quality and structure of the land. The composition and quality of land resources of the South Kazakhstan region in the context of rural areas are presented in table 2.

On the October 1, 2019, 19 biofactories and a biolaboratory operate on the territory of the Maktaaral district of the South Kazakhstan region, with which 39036.4 ha of the sown area were cultivated. The average productivity of existing biofactories is 2055 ha (39036.4 ha / 19). Based on this, the cadastre of biolaboratory and biofactories in the context of rural areas of the Turkestan region was developed in accordance with table 3. According to the state of land resources in rural areas of the South Kazakhstan region in the Otyrar, Suzak and Shardara districts, natural and climatic conditions are favorable for the cultivation of melons, unfavorable for the propagation of plant pests (sands, deserts).

Table 2 - The composition and quality of land resources of the South Kazakhstan region in the context of rural areas

\begin{tabular}{|l|c|c|c|c|c|c|c|}
\hline \multicolumn{1}{|c|}{ Region } & $\begin{array}{c}\text { Floodplain } \\
\text { meadows }\end{array}$ & Sands & $\begin{array}{c}\text { Light } \\
\text { chestnut } \\
\text { and grey } \\
\text { humus }\end{array}$ & Deserted & $\begin{array}{c}\text { Foothills } \\
\text { and steppe } \\
\text { grey and } \\
\text { dark humus }\end{array}$ & $\begin{array}{c}\text { Mountain } \\
\text { forest chestnut } \\
\text { and grey } \\
\text { humus }\end{array}$ & Bonitet score \\
\hline 1. Baidibek & $3 \%$ & & $51 \%$ & & & $46 \%$ & 12,7 \\
\hline 2. Kazygurt & & & $65 \%$ & & & $35 \%$ & 20,4 \\
\hline 3. Maktaaral & & & & & $100 \%$ & & 20,0 \\
\hline 4. Ordabasi & $20 \%$ & & $80 \%$ & & & & 15,3 \\
\hline 5. Otyrar & $15 \%$ & $70 \%$ & $15 \%$ & & & & 11,4 \\
\hline 6. Sairam & $20 \%$ & & $80 \%$ & & & & 22 \\
\hline 7. Saryagash & $6 \%$ & & $94 \%$ & & & & 11 \\
\hline 8. Suzak & $12 \%$ & $20 \%$ & $3 \%$ & $50 \%$ & & $10 \%$ & 12,2 \\
\hline 9. Tolebi & & & $40 \%$ & & & $60 \%$ & 28,2 \\
\hline 10. Tulkubass & $33 \%$ & & $34 \%$ & & & & 33 \\
\hline 11. Shardara & $8 \%$ & $88 \%$ & $1 \%$ & & $3 \%$ & & 8,4 \\
\hline
\end{tabular}

Accordingly, in these areas, the costs of plant protection will be significantly lower than, for example, in the Maktaaral district.

Natural and climatic conditions (deserts and semi-deserts) in the Suzak region contribute to the intensive development of cattle breeding, in particular, the breeding of camels and sheep. Crop production in this area is represented only by the cultivation of fodder crops, which for the most part are not fully cultivated and are able to independently resist diseases and pests, for which there is no need to carry out protective measures.

The ecological state of the region, which is due to the proximity of the Aral and Baikonur and the presence of uranium deposits, also adversely affects the development of crop production. Therefore, in the Suzak, Maktaaral and Otyrar regions of the Turkestan region, the creation of biological laboratories and biofactories is considered inappropriate (Table 3, p. 113). 
Table 3 - Calculation of the need for biological laboratories in the context of rural areas of the Turkestan region

\begin{tabular}{|c|c|c|c|c|c|c|c|}
\hline $\begin{array}{l}\text { Rural } \\
\text { areas of } \\
\text { Turkestan } \\
\text { region }\end{array}$ & $\begin{array}{l}\text { Sown } \\
\text { area, ha }\end{array}$ & \begin{tabular}{|l|} 
Area \\
Specialization
\end{tabular} & $\begin{array}{l}\text { Areas with } \\
\text { unfavorable } \\
\text { breeding } \\
\text { conditions } \\
\text { for plant } \\
\text { pests }\end{array}$ & $\begin{array}{l}\text { Calculation } \\
\text { of the need } \\
\text { for bio- } \\
\text { laboratories } \\
\text { (with a } \\
\text { typical bio- } \\
\text { laboratory } \\
\text { productivity } \\
\text { of } 2600 \text { ha) }\end{array}$ & $\begin{array}{l}\text { Calculation of the } \\
\text { need for biological } \\
\text { laboratories (with } \\
\text { a productivity } \\
\text { of } 2055 \text { hectares } \\
\text { operating in the } \\
\text { Maktaaral district } \\
\text { of the Turkestan } \\
\text { region) }\end{array}$ & \begin{tabular}{|l|} 
The \\
required \\
number of \\
biological \\
laboratories \\
(average \\
value)
\end{tabular} & $\begin{array}{l}\text { The number } \\
\text { of new jobs } \\
\text { with the } \\
\text { number of } \\
\text { employees } \\
\text { at one } \\
\text { biofactory } \\
\text { is } 22 \text { people }\end{array}$ \\
\hline Baidibek & 88955,4 & $\begin{array}{l}\text { Wheat, safflower, } \\
\text { potatoes, } \\
\text { vegetables, } \\
\text { gourds }\end{array}$ & & 34 & 43 & 38 & 836 \\
\hline Kazygurt & 82776,5 & $\begin{array}{l}\text { Wheat, safflower, } \\
\text { potatoes, } \\
\text { vegetables, } \\
\text { apples, grapes, } \\
\text { corn }\end{array}$ & & 32 & 40 & 16 & 352 \\
\hline Maktaaral & 138210,8 & $\begin{array}{l}\text { Cotton, gourds, } \\
\text { corn, vegetables, } \\
\text { sunflowers, } \\
\text { grapes, rice, } \\
\text { potatoes } \\
\end{array}$ & & 53 & 67 & 60 & 1320 \\
\hline Ordabasy & 55172,1 & $\begin{array}{l}\text { Vegetables, } \\
\text { crops, potatoes, } \\
\text { cotton, grapes, } \\
\text { gourds, apples } \\
\end{array}$ & & 21 & 27 & 24 & 528 \\
\hline Otrar & 28050,0 & $\begin{array}{l}\text { Corn, gourds, } \\
\text { sunflower, } \\
\text { vegetables } \\
\end{array}$ & + & - & - & - & - \\
\hline Sairam & 47188,5 & \begin{tabular}{|l} 
Fruits, grapes, \\
vegetables, \\
potatoes, \\
safflower, wheat \\
\end{tabular} & & 18 & 23 & 21 & 462 \\
\hline Saryagash & 81724,2 & \begin{tabular}{|l|} 
Sunflower, \\
vegetables, \\
potatoes, gourds, \\
grapes
\end{tabular} & & 31 & 40 & 36 & 792 \\
\hline Suzak & 13005,4 & $\begin{array}{l}\text { Corn, potatoes, } \\
\text { vegetables, fruits }\end{array}$ & + & - & - & - & - \\
\hline Tolebi & 64651,1 & $\begin{array}{l}\text { Safflower, wheat, } \\
\text { fruits, potatoes, } \\
\text { vegetables }\end{array}$ & & 25 & 31 & 28 & 616 \\
\hline Shardara & 59290,5 & $\begin{array}{l}\text { Safflower, fruits } \\
\text { and berries, } \\
\text { wheat, grapes, } \\
\text { potatoes, } \\
\text { vegetables } \\
\end{array}$ & + & - & - & - & - \\
\hline Total & 659024 & & & 214 & 271 & 223 & 4906 \\
\hline
\end{tabular}

Based on the analysis of crop development in the Turkestan region, the following problems were identified:

- decrease in the fertility of agricultural land;

- recommendations of research institutions regarding crop rotation compliance are not being implemented on the ground;

- Soil and climatic features and market conditions are not taken into account when growing vegetables, fruits, berries, melons and grapes. 
In order to optimize the structure of sown areas at the oblast level, the following measures are proposed:

- for the formation of a competitive industry, it is necessary to be guided by scientifically based methods of crop production and regional specialization;

- according to the development strategy of the southern region, it is necessary to increase the sown area of grapes, fruit crops, vegetables and melons according to the cluster principle;

- the formation of a system of elite seed farming of agricultural plants;

- an increase in the production capacities of industrial enterprises that process fruits and vegetables and grapes;

- the use of fertile agricultural land that has gone out of circulation for various reasons (crisis, lack of labor, agricultural machinery, etc.);

- development of the regional information and marketing system.

Consequently, timely biologization of protective measures against cotton pests in the south of Kazakhstan will stabilize the ecological situation in this region.

\title{
LIST OF LITERATURE
}

1 Сагитов А.О. Будущее за биологической защитой растений // Жаршы. - 2017. - № 3. - С. 3-7.

2 Исмухамбетов Ж.Д. Пути развития биологического метода защиты растений // Вестник с-х науки Казахстана. - 2016. - № 5. - С. 3-8.

3 Шаповал С. Требование к типовым биолабораториям и фабрикам: www.mgov.kz/wp.../ TREBOVANIYA-k-tipovyim-biolaboratoriyam-i-biofabrikam-ru.docx. 15.11.2016.

4 Дуйсембеков Б.А., Исмухамбетов Ж.Д. Состояние и перспективы развития биологического метода защиты хлопчатника от основных вредителей в Южном Казахстане // Казахстан в новом мире и проблемы национального образования: тр. междунар. науч.-практ. конф., посв. 10-летию ун-та «Сырдария». - Жетысай, 2018. - Т. ІІІ (Естественные науки). - С. 419-423.

5 Исмухамбетов Ж.Д., Сагитов А.О. Актуальные задачи защиты и карантина растений в Казахстане // Защита и карантин растений в Казахстане. - 2015. - № 2. - С. 2-7.

6 Исмухамбетов Ж.Д., Сагитов А.О., Б.А. Дүйсембеков, Н.К. Кашкенов. Оңтүстік Қазақстанда мақтаны зиянкестерден қорғау жөніндегі ұсыныстар. - Алматы: Бастау, 2019. - 21 б.

7 Сайлыбаева А.Б. Зарубежный опыт внедрения нововедений в сферы растениводства и животноводства // КазЭУ Хабаршысы. - 2015. - № 2. - С. 121.

8 Тулегенов Б.Т., Бельгибаева Ж.Ж. Продовольственная безопасность и здоровое питание населения Казахстана // Пищевая и перерабатывающая промышленность Казахстана. - 2015. - № 1. - С. 10.

Ж.Е. АБЫЛГАЗИЕВА, ${ }^{1}$

Э.Ғ.К.

Г.Р. ДУЙСЕМБЕКОВА,

Э.Ғ.К.

A.H. РАМАШОВА, ${ }^{2}$

$\mathrm{PhD}$.

M. Сапарбаев атындағы Оңтүстік Қазақстан гуманитарлық институты. ${ }^{1}$

M.О. Әуезов атындағы Оңтүстік Қазақстан мемлекеттік университеті ${ }^{2}$

\section{ӨСІМДІКТЕРДІ ҚОРҒАУДА БИОЛОГИЯЛЫҚ ӘДІСТЕРДІ ҚОЛДАНУДЫҢ ЭКОНОМИКАЛЫҚ ТИІМДІЛІГІ}

\begin{abstract}
Андатпа
Өсімдіктерді қорғаудың биологиялық әдістерін қолданудың экономикалық тиімділігі зерттелді. Түркістан облысындағы ауыл шаруашылығы және оның ішінде өсімдік шаруашылығы жағдайына талдау жүргізілді. Өсімдіктерді қорғаудың биологиялық әдістерін пайдаланудың шетелдік тәжірибесі зерттелді және оларды Қазақстан жағдайында қолдану жолдары анықталды. Ауылдық аумақтарды жіктеу әлеуметтік-экономикалық
\end{abstract}


дамуды, оның ішінде экономикалық әлеуетті сипаттайтын көрсеткіштер бойынша жүргізілді. Өсімдіктерді қорғау әдістерінің мәні анықталды, Түркістан облысы Мақтаарал ауданындағы мақтаның егіс алаңдарында биоагенттерді қолданудың экономикалық тиімділігін есептеу жүргізілді, өсімдіктерді қорғаудың биологиялық әдістерін қолданудың шетелдік тәжірибесі зерттелді және оны Қазақстанда енгізу жолдары қарастырылды, биолабораторияларға қажеттілік есебі жүргізілді, зерттеу нәтижелері қорытындыланды. Авторлар өсімдіктерді қорғаудың биологиялық әдістерін қолданудың тиімді екенін дәлелдеді. Түркістан облысының көптеген ауыл шаруашылығы құрылымдарында тамшылатып суару жүйесін пайдаланады. Бұл жағдайда оқпан ауданында және табақ бетінің жанында ауаның жоғары ылғалдылығы кезінде биопрепараттарды қолдану тиімділігі жоғары болады, өйткені жоғары ылғалдылық жағдайында әсер етуші заттың негізін құрайтын бактериялар мен саңырауқұлақтар анағұрлым өнімді және вирулентті.

Тірек сөздер: жіктеу, биологиялық әдістер, өсімдіктер қорғау, экономикалық әлеует, биопрепарат, биолаборатория, жоғары ылғалдылық, өндіріс, ресурстар, суару жүйесі, аудан, тиімділікті бағалау.

Ж.Е. АБЫЛГАЗИЕВА,

К.Э.Н.

Г.Р. ДУЙСЕМБЕКОВА, ${ }^{2}$

К.Э.Н.

A.H. PAМАШOBA, ${ }^{2}$

$\mathrm{PhD}$.

Южно-Казахстанский гуманитарный институт им. М. Сапарбаева ${ }^{1}$

Южно-Казахстанский государственный университет им. М.О. Ауэзова²

\title{
ЭКОНОМИЧЕСКАЯ ЭФФЕКТИВНОСТЬ ПРИМЕНЕНИЯ БИОЛОГИЧЕСКИХ МЕТОДОВ ЗАЩИТЫ РАСТЕНИЙ
}

\begin{abstract}
Аннотация
В статье исследована экономическая эффективность применения биологических методов защиты растений, проведен анализ состояния сельского хозяйства и, в частности, растениеводства в Туркестанской области, рассмотрен зарубежный опыт использования биологических методов защиты растений и определены пути их применения в условиях Казахстана. Классификация сельских территорий произведена по показателям, характеризующим социально-экономическое развитие, в том числе экономический потенциал. Определена сущность методов защиты растений, произведены расчеты экономической эффективности применения биоагентов на посевных площадях хлопчатника в Мактааральском районе Туркестанской области, исследован зарубежный опыт применения биологических методов защиты растений и рассмотрены пути его внедрения в Казахстане, произведен расчет потребности в биолабораториях, обобщены результаты исследования. Авторами обоснована эффективность применения биологических методов защиты растений. Во многих сельскохозяйственных формированиях Туркестанской области используют капельную систему орошения. Как известно, в этом случае при более высокой влажности воздуха в районе ствола и возле листовой поверхности эффективность применения биопрепаратов становится выше, так как в условиях повышенной влажности бактерии и грибы, составляющие основу действующего вещества, более продуктивны и вирулентны.
\end{abstract}

Ключевые слова: классификация, биологические методы, защита растений, экономический потенциал, биопрепарат, биолаборатория, высокая влажность, ресурсы, система орошения, площадь, оценка эффективности. 